\title{
Friendly Relations between Iran and Azerbaijan: A Review
}

\section{Taghi Davoodi}

\author{
PhD in Political Science, Faculty of International Relation and International Law, University Of Baku, Azerbaijan
} Email: davoodi.taghi@gmail.com

\section{Doi:10.5901/mjss.2016.v7n5p259}

\begin{abstract}
The relation between Iran and Azerbaijan has been formed based on Islamic law, democracy, and the factors that bind the two nations together for many years. Iran and Azerbaijan share, to a large extent, a same history, religion, and culture. Our purpose in this study is reviewing the factors affecting development of relations between the two neighboring countries. The studies on the relations between Iran and Azerbaijan in the recent period indicate that the necessary researches have been carried out in this field and many resources are now available. By reviewing these works and latest developments, we can say that Azerbaijan-Iran bilateral relations is gradually improving especially with the advent of Iranian president Hassan Rouhani, and both have tendency to grow their relations by signing more treaties for cooperation in many sectors.
\end{abstract}

Keywords: Political science, international relations, development, Iran, Azerbaijan

\section{Introduction}

"Iran has always held a special place in the foreign policy of Azerbaijan, one of the Caucasian nations. Having made a long historical way together and even been part of the same states throughout centuries, the two countries share the same religion and similar customs. In fact, the country named Azerbaijan was divided between Russia and Iran in the 1810-1820s. The northern Azerbaijan that fell under the tsarist rule later earned a brief independence (1918-1920), got incorporated into the USSR (1920-1991), and finally regained independence in 1991. The southern territories have been part of Iran ever since, with Azerbaijani residents ranging from 15 to 30 million, the largest population of ethnic Azerbaijanis" (Huseynov, 2015). "Ongoing tensions between Azerbaijan and Iran have filled the press in both countries for the past five years. However, these bilateral frictions have begun to deescalate since Azerbaijani President Ilham Aliyev's visit to Iran and newly inaugurated Iranian President Hassan Rouhani visited Baku." (Gafarli, 2014)

About the relations of Iran and Azerbaijan and international relations, different studies have been conducted by the scholars of both countries. Safarali and Alibeyoğlu (1994) in his book Tarixin Dord Gunu (Four days of the history) discussed about Heydar Aliyev's official visit to Iran in 29 June 1994, and the results of interviews and press conferences of the leaders of the two countries. Soltanzadeh and Vardiev (2003) investigated the evolution of bilateral relations in the past two decades. Abdullayev (2000); Musayev (2001); Hassanali (1993); and Piriyev (2002) each of these works studied relations between Iran and Azerbaijan and international relations. Among Persian works, Amir Ahmadian (2005) discussed political, economic, cultural and strategic issues between two neighboring countries; Mollazadeh (1994) in his book implied cultural commonalities between the two countries such as Nowruz, shared history, and traditional customs; Koolaee (1997) studied governments, politics, and revolutions by given the name of the leaders of the Soviet Union and completed it by stating the 1991 Soviet coup and the collapse of this government. Zoleyn (1998) focused on the nature of international law, UN relations, formation and development of community, and relations of legal systems; Mansouri (1995), Esmaeilzadeh (2004), Haji Yousefi (2005), Zarif and Zahrani (2005), and Omidvarnia (1995) each studied foreign policy of Iran, developments, relations, and history of the Soviet Union. Sheikh Attar (1994) discussed political behavior in Central Asia and the Caucasus; Moghtader (1978) concerned the developments in the United Nations; Saghafi Ameri (1997) many aspects of the United Nations, its Charter, international social cooperation, and other important issues. By considering previous studies and present events in the international arena, in this study we have a look at friendly relations between Iran and Azerbaijan. Our purpose is reviewing their cultural affinity, language, civility and respect for good neighborliness as well as providing background to the development of relations between the two countries with humanitarian assistance in various areas based on the criteria of the UN Charter. Existence of resources and wide range of topics in international relations provided good facilities for us in terms of quantity and quality. In this regard, library method and online searching were performed for collecting the information. First we provide the study background, and then by reviewing relations between Iran and Azerbaijan from the past to present, we present our conclusion and recommendations. 


\section{Background}

Latest developments, especially in the late twentieth century and early twenty-first century, the emergence of the growing phenomenon of science and technology, international community communications and the collapse of Europe socialist system, and The Soviet Union influenced the structure of international relations which means not only created fundamental changes in the light of the awakening of the people of the Caucasus and Central Asian, but also by the collapse of the Soviet Union, the newly independent republics of the former Soviet Union found their place in the political, cultural, and economic arena. Although this type of independence is not always free of problems and always put the new issues facing the neighboring countries but for the actors of international life, it is a chance to take full advantage from the political gap existing in the territory of the former Soviet Union in order to achieve the of economic, political, military objectives . It is clear that, today, as a result of modern technology, reflection of any events in every corner of the world within the shortest time will manifest the relations of countries. In this regard, the duty of the international community is to provide the field of peaceful cooperation in international affairs, avoid potential risks, and respect public diplomacy.

Republic of Azerbaijan was separated from the Soviet Union and restored its independence in 18 October 1991 and hence, as a sovereign state, entered into global community. This transitional period that was associated with undulating events attracted the attention of ancient Iran which itself had governance practices for thousands of years and had well-known place in the international community. It is worth mentioning that Iranian empire, despite this position and popularity, had and has its own staunch enemies. It is clear that regardless of some political ups and downs, in such circumstances, the position of Azerbaijan in terms of the neighborhood, shared history, culture, and religion which bind the people of two countries together, is of great importance in Iran's foreign policy. Passage of time and experience of international relations indicate that relationships which are based on religion, language, and common culture is productive and lasting than official government relations, i.e. cooperation of great mass of people in relations between governments leaves a positive effect on the quality of these relations, and gives it a new nature. These features show themselves in relations between Iran and Azerbaijan, prominently. Of course experts by implying these beliefs, emphasize that relations have to be formed and developed based on both friendship, good neighborliness, and the rules derived from international law, and framework of the idea of "Islamic Union". This theory itself is considered as a part of the philosophy of foreign policy of the Islamic Republic of Iran, because on this basis, the establishment and development of all aspects of relations between Islamic countries is a priority of Iran's foreign policy

\section{Relations between Iran and Azerbaijan from the Past to Present}

The relation between Iran and Azerbaijan has been shaped based on Islamic law, democracy, and the factors that bind the two nations together for a long time. Diplomatic and political relations between the two countries started in twentieth century. In March 1920 after nearly three months of negotiations in an atmosphere of mutual understanding, the Democratic Republic of Azerbaijan was recognized by Iran and relations were established between the two countries in embassy level. It should be mentioned that at that time Iran was the only country that recognized the Democratic Republic of Azerbaijan as an independent state. According to the protocol signed between the two governments, Azarbaijan constructed its consulates in Iranian cities of Tehran, Urmia, Anzali, and Mashhad, and one consular agency in Ahar. Opening many diplomatic agencies of Iran in Azerbaijan was also carried out. Constructing many agencies and consulates by the two countries was the indication of the expansion of relations.

By the occupation of Azerbaijan by the 11th Red Army in 1920, and the establishment of a socialist government, the political relations between Iran and Azerbaijan was interrupted till 1991. However, as mentioned before, these relations were resumed in 1991 when Azerbaijan Republic declared its independence from the Soviet Union. In 8 December 1992, Azerbaijan's ambassador submitted his credentials to President of Iran Hashemi Rafsanjani. Official opening of embassies in the capitals of the two countries improved relations between the two friendly and neighboring countries. The conditions were prepared for solving practical problems in the way of the development of relations. As time passed, the parties signed many treaties, documents, agreements, and memorandum of understanding which shows the expansion of relations between the two countries. Official visits of former and current Iranian presidents to Azerbaijan and official visits of Azerbaijani president to Iran resulted in development and progress of relations between the two neighboring countries. One of the factors that left great impact on the relations between the two countries was the development of trade and economic relations based on mutual interests such as Economic Cooperation Organization (ECO) with regional expansion and modernization of its activities, securing the borders and formation of cross-border committee, acceleration of the development of communication roads and north-south railways, and the provision of economic necessary infrastructures. Another factor in the relations between Iran and Azerbaijan is the active role of the 
great masses of the people in preserving cultural ties such as celebrations including Eid Nowruz. Dastgahs (i.e. musical instruments) such as Chahargah, Segah, Homayoun, Bayat-e Tork, and Shur are considered as cultural commonalities between Iran and Azarbaijan. "For Azerbaijan, the Islamic Republic of Iran is not just an ordinary country. First of all, Iran is the Azerbaijan Republic's southern neighbor. The two states share about 618 kilometers of land borders. These two countries border each other in the Caspian Sea as well. Both countries share values from their mutual past and some elements of a common culture. Azerbaijan has the second largest Shili population in the world, after Iran. The membership of both countries in Muslim and regional organizations like the Organization of Islamic Conference and ECO, is an indicator of the countries' affinities in terms of geography and religion" (Nassibi, 2014).

"With the advent of Hassan Rouhani as president of Iran in late 2013, relations between the two neighbouring countries have improved. Rouhani met with Aliyev in Davos, Tehran, Astrakhan and, now most recently, in the Azerbaijani capital. According to Rouhani, the meetings between the two presidents have taken place in four stages, and these progressive summits were important steps in improving bilateral relations. Rouhani emphasized that he was keen on developing the relations between the two countries in all directions" (Gafarli, 2014). "Speaking about relations with Iran in May 2015, President Ilham Aliyev said the Iranian-Azerbaijani friendship is unbreakable and no extraneous force can split it" (Orujova, 2014).

Early April of 2015, "the news spread from Switzerland reported a long-awaited arrangement: Iran and six world powers that had negotiated for the past several years declared a deal, which would block Tehran from developing nuclear weapons in exchange for the lifting of Western sanctions. Despite some skeptical opinions, the most agreed it was a big diplomatic achievement and hoped for further warming in the relations between Iran and the Western world. the nuclear deal will influence the global geopolitics, as well as Iran`s neighborhood, the Caucasus" (Huseynov, 2015).

\section{Conclusion}

Republic of Azerbaijan in foreign policy of the Islamic Republic of Iran maintains has special place due to the proximity and commonality that bind the people of two countries together. These longstanding ties are based on solid foundation which consists of religion, language, rich cultural heritage, and common traditions. Iran always supports Azerbaijan civilization before and after its independence in micro and macro levels and welcomes the agreement in communications media, and believes that cultural and political tension between the its north neighbors in the shadow of negative propaganda the shadow of negative propaganda of other countries, have adverse effect on Iran and Azerbaijan.

There are some recommendations which can play decisive roles in the expansion of relations between the two countries:

- Some political problems which are common in the international relations should not prevent the development of relations between the two Muslim countries which is based on the principles of good neighborliness and brotherhood;

- It is necessary that, based on wisdom and tact, the two countries never interfere in each other's internal affairs;

- In order to expand economic relations between the two countries, completing valid legal procedures (e.g. contracts, agreements) at the governmental level is necessary;

- Since both countries are of the Caspian Sea littoral states, they should react to the aggressive intentions and actions of any foreign government and provide favorable conditions to maintain peace, security, and stability in the Caspian Sea basin.

\section{References}

Abdullayev, M. (2000). History of International Relations. Baku. [In Azeri]

Amir Ahmadian, B. (2005). Ravabete Iran va Jomhoriye Azarbayjan [Relations between Iran and Azerbaijan]. Tehran: Ministry of Foreign Affairs.

Esmaeilzadeh, R. (2004). Daste Dosti [Hand of Friendship]. Baku: Alhoda,

Gafarli O. (2014). Azerbaijan Seeks Warmer Ties With Iran. Eurasia Daily Monitor, 11 (216). Available at: http://www.jamestown.org/ programs/edm/single/?tx_ttnews\%5Btt_news\%5D=43152\&cHash=6b921a9e465289b9f0741d7b66537537\#.VILBw3arTIU

Haji Yousefi, A. M. (2005). Siasate Kharejie Jomhoryie Eslamie Iran [Foreign Policy Of Islamic Republic Of Iran]. Tehran: Ministry of Foreign Affairs.

Hassanali, J.(1993). Azerbaijan Republic in the system of International Relations. Baku. [In Azeri]

Huseynov R. (2015). Azerbaijan after the Iran Nuclear Deal. Retrieved Oct 2015 from http://www.thewashingtonreview.org/articles/ azerbaijan-after-the-iran-nuclear-deal.html 
Koolaee, E. (1997). Ettehade Jamahire Shouravi az Takvin ta Foropashi [ The Soviet Union: from creation to collapse]. Tehran: Ministry of Foreign Affairs.

Mansouri, J. (1995). Farhange Esteghlal va Tose'e [Culture of independence and development]. Tehran: Ministry of Foreign Affairs.

Mollazadeh , H. ( 1994). Jomhorie Azarbaijan [Republic of Azerbaijan]. Tabriz, Iran: Arak,.

Moghtader, H. (1978). Tahavolate Sazmane Melal [Developments in the United Nations]. Shiraz, Iran: Shiraz University.

Musayev, E. (2001). Foreign Policy of Azerbaijan. Baku. [In Azeri]

Nassibli, N. (2014). Azerbaijan- Iran Relations: Challenges and Prospects (Event Summary). Kennedy School of Government, Harvard University. Retrieved Oct 2015, Available at: http://belfercenter.ksg.harvard.edu/publication/12750/azerbaijan_iran_ relations.html

Orujova N. (2014). Iranian-Azerbaijani friendship unbreakable, Aliyev says. Retrieved 10 May 2015 from http://www.azernews.az/ azerbaijan/73220.html

Omidvarnia, M. J. (1995). Rishehaye Degargoni dar Ettehade Jamahire Shouravi [The roots of change in the Soviet Union]. Tehran: Ministry of Foreign Affairs.

Piriyev, A. (2002). Siyasi strategiya vă milli tahluikašizlik problemi [Political strategy and the problem of national security]. Baku: Bakı Dövlat Universiteti.

Saghafi Ameri, N.( 1997). Sazmane melale Motahhed [United Nations]. Tehran: Ministry of Foreign Affairs

Safarali A., and Alibeyoğlu H. (1994). Tarixin Dord Gunu [Four days of the history]. Tehran: Sorush

Soltanzadeh, V. and Vardiev, G. (2003). Heydar Aliyev va Shargh [Heydar Aliyev and the East]. Baku: Chashioglu, Embassy of the Islamic Republic of Iran.

Sheikh Attar, A. (1994). Rishehaye Raftare Siasi dar Asiaye Markazi va Ghafghaz [The origins of political behavior in Central Asia and the Caucasus]. Tehran: Ministry of Foreign Affairs

Zarif, M.J., \& Zahrani, M. (2005). Ravandhaye Jadide Beynolmelali [New International Trends]. Tehran: Ministry of Foreign Affairs Zoleyn, P.(1998). Mabani Hoghoghi Beynolmelale Omomi [Principles of Public International Law]. Tehran: Ministry of Foreign Affairs. 